\title{
Maternity, paternity, and parental rights of doctors in the UK
}

\author{
Anne L Grüneberg
}

Doctors' rights to maternity leave in the United Kingdom are bogged down in a complicated system, and rights of paternity or parental leave usually don't exist for them. These rights are discussed in connection with money and time away from work with job security for new parents. Maternity leave rights relate to the time between the 11th week before the expected week of delivery and 29 weeks after delivery. The term parental leave usually refers to leave taken after this period by either parent. Paternity leave is the term used for any leave taken by the father at the time of the birth and immediately afterwards.

\section{Maternity rights}

JUSTIFICATION FOR SUCH RIGHTS FOR WOMEN DOCTORS

It is currently accepted that the good health of the mother, breast feeding, care from the parents, and adequate living conditions are beneficial to a newborn child. Two prerequisites for these circumstances are sufficient money and time.

Time

Some of the needs of a doctor mother in respect of time away from work conflict with some of those listed for the child. Changes could be made to the system which would reduce this conflict, but it would still exist.

Full use of the public money spent in training women doctors and full use of their educational achievement and acquired skills depend on women doctors not being absent from work for long periods. Such absence is especially detrimental to developing medical skills and to career progression. in the present system if it happens before the age of 30 , the optimal period for childbearing. Yet it can make no sense in terms of social policy to discourage thousands of the United Kingdom's most intelligent women from breeding, as has happened to past generations of women doctors.

The difficulties of balancing the demands of a pounded by the problems which may be caused to an employer and colleagues when an employee is away on maternity leave. The perceived unpredictability of timing of an absence and of the doctor's intentions concerning return to work in the long term create difficulties, particularly in small staff groups. In practice most women doctors are sufficiently strongly motivated to accurately predict their course of action. Changes in the postgraduate training system to reflect training needs rather than tradition, the abolition of short term contracts, and a better system for covering absence would do more to reconcile the interests of child, employer, and doctor mothers than changes in maternity rights.

67 Cholmeley Crescent, London N6 5EX

Anne L Grüneberg, FFARCS, consultant anaesthetist Money

In contrast to the continuing difficulties associated medical career with those of motherhood are com-

with pregnancy and spending time away from work the basis of the money aspect is satisfactory. Statutory maternity payments arise from rights connected with national insurance contributions. This rules out the unreasonable expectation for an employer to finance maternity payments, which applies in the United States. ${ }^{2}$ There is minimal long term expenditure for an employer in the UK despite misconceptions to the contrary.

The present maternity rights in the UK that encompass paid maternity leave and job security for women doctors form a ludicrously complicated and flawed but useful basis for developing a system that will take account of the short term and long term needs of the child, the mother, and the employer.

\section{HISTORY ${ }^{3}$}

In the UK legislation affecting maternity rights has concentrated on an expectant mother's need for money and, more recently, has provided the option of returning to work after maternity leave. Legislation in the United States developed from a perceived need to prevent a woman from working late in pregnancy.

The 1911 National Insurance Act introduced a maternity grant payment of 30 shillings (£1.50). Maternity payments have steadily increased, though they have not always kept pace with inflation. The well intentioned Employment Protection Act 1975 gave an employee protection against dismissal on grounds of pregnancy after six months in a post and 40 weeks' maternity leave after two years' service with an employer. This Act made employers wary of taking on new employees, particularly women, including women doctors. In some quarters the Act was christened the "Employment Prevention Act." Employment legislation in 1985 increased the qualifying period to two years for protection against dismissal on grounds of pregnancy, which would be expected to increase the employment opportunities for women while reducing their rights in connection with job security. Some categories of employment are excluded from statutory rights to return to work after childbirth, such as doctors employed in the armed forces.

The pre-existing Whitley Council provision of 18 weeks' maternity leave for NHS and local authority employees has been extended for those covered by the Employment Protection Act to up to 40 weeks' leavea long period away from work for a young doctor who is establishing a career. Although uninterrupted employment by different health authorities counts as continuous service for Whitley Council purposes, statutory maternity rights depend upon service with one employer, which is interpreted in the NHS as one health authority. Under Whitley Council provisions maternity pay may be claimed for up to 18 weeks' absence from work on maternity leave, which is also the maximum number of weeks for which statutory maternity payments are claimable. The 1986 Social 
The 23 week period including expected week of delivery and the 18 week pay period

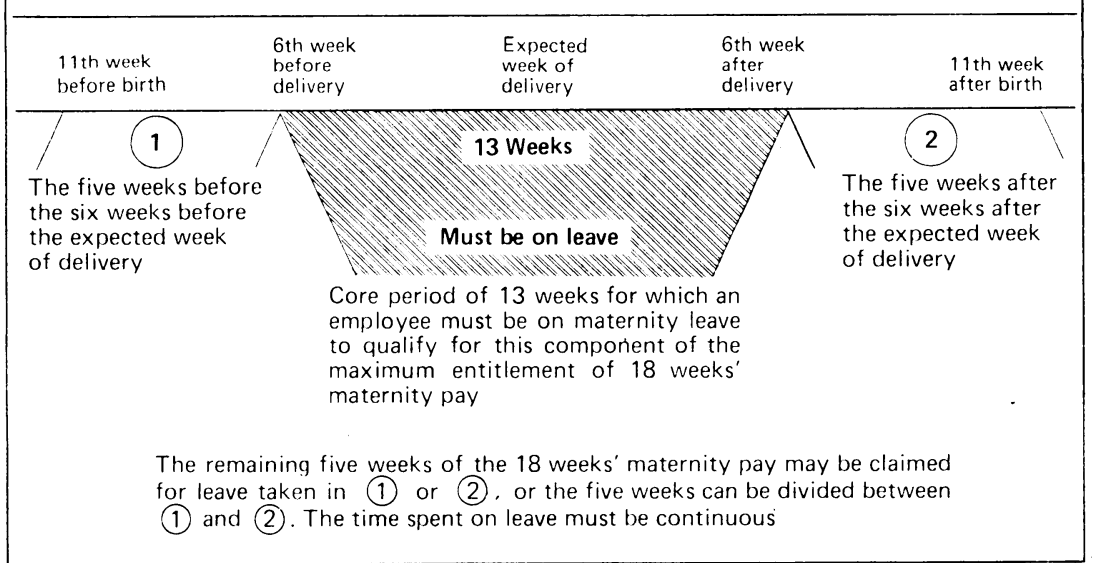

combined the previous maternity pay and maternity allowance into a single payment - statutory maternity pay - for those eligible for it.

\section{ADVICE TO WOMEN DOCTORS}

Careful consideration should be given to the timing of any pregnancy to avoid the Scylla of elderly motherhood and the Charybdis of difficulties with essential postgraduate experience and examinations, and short term contracts, early in a medical career. Information about maternity rights is helpful to a woman doctor who is considering whether or not to have a baby and if so, when. Such information is vital once she becomes pregnant. A newly pregnant woman doctor is advised to clear a working day to study relevant publications and to arrange for a two hour tutorial on the subject from a well informed personnel officer or a member of the staff of Maternity Alliance. ${ }^{3}$

She will discover that her employment state five, three, and two years ago, 15, 11, and six weeks before the expected week of delivery, and six, 11, and 29 weeks after delivery all may affect her entitlement. She may find that she has no maternity rights because she has changed her employer or is on a short term contract. She should talk to at least one woman doctor who has recently returned to work after maternity leave and at least one working woman doctor with older children. She should then decide what she is going to do in terms of the length and timing of any leave she intends to take and whether or not to return to the same job or find a different job, and she should then adhere to these decisions if it is humanly possible, even if they subsequently seem wrong, until at least nine months after delivery. This is necessary for the doctor's peace of mind and her reputation and that of her female colleagues. She is advised to enter on a wall chart, for instance, all the dates for relevant submissions and certificates. The requirements and complications have doubled in the last 10 years.

\section{CURRENT MATERNITY RIGHTS}

Details of requirements for eligibility for maternity payments, leave from work, and job security are set out in leaflets on maternity rights, such as those available from the Medical Women's Federation and the National Council for Civil Liberties. There is no up to date leaflet available from the BMA.

The following list of some of the maternity payments does not reveal the complexities.

Payments that may be claimable include: (i) welfare payments; (ii) sickness benefit at $£ 31$.30 a week; (iii) maternity allowance at $£ 31.30$ a week; (iv) statutory maternity pay at $£ 34.25$ a week for up to 18 weeks; $(v)$ higher rate statutory maternity pay at approximately
$90 \%$ of weekly salary for up to six weeks; (vi) occupational maternity pay.

Doctors who work in the NHS or for a local authority or as trainees in general practice may be eligible for occupational maternity pay provision as agreed through Whitley Council. This provision amounts to up to six weeks at approximately $90 \%$ of salary plus up to 12 weeks at approximately $50 \%$ of salary.

Most of these payments are mutually exclusive.

\section{DOCTORS WHO ARE EMPLOYEES}

The amount of time spent away from work with job security is likely to be none, up to 18 weeks, or up to 40 weeks (box). The maximum amount of money claimable is likely to be up to 18 weeks' maternity pay - often called the maternity pay period. The time spent on leave must be continuous.

NHS GENERAL PRACTITIONER PRINCIPALS OR ASSISTANTS

Principals in general practice are not employees. They may be eligible for maternity payments from the relevant family practitioner committee (health board in Scotland). If a locum is employed during a principal's absence because of pregnancy up to $£ 262.50$ a week is claimable for 13 weeks provided certain criteria are met. These include a minimum number of patients on the doctor's list and a requirement to return to work after the birth. Similar provisions exist for assistants in general practice who are recognised by the family practitioner committee or health board, although they are employees. Assistants not so recognised may be eligible-as employees - for higher rate statutory maternity pay or a lower rate, or both, or maternity allowance for up to 18 weeks. The stringency of the criteria applying to principals and recognised assistants has created difficulties. Further difficulties stem from the fact that provision for maternity leave in general practice has developed from provision for incapacity. It would be more appropriate for pregnancy to be regarded as an onerous but rewarding task. Unnecessary discrepancies between principals and assistants and between the different classes of assistants should be abolished.

\section{SELF EMPLOYED OR UNEMPLOYED DOCTORS}

A self employed or unemployed doctor may be eligible for up to 18 weeks of maternity allowance because of having paid National Insurance Contributions. Sickness benefit for up to eight weeks may be claimable if National Insurance payments have been made in the past but not recently. Any welfare benefit claimable will be means tested and may include a maternity payment of $£ 80.00$.

\section{Paternity rights}

It might be suggested that some fathers may not wish to give moral support to their labouring spouses or be present at the birth. Others would say that this should go with the job. There is no statutory or Whitley Council provision for paternity leave. Though more than 50 British firms provide paternity leave for employees, this is unlikely to be relevant for men doctors. What this means in practice is that senior, well established men doctors take informal (paid) leave by arrangement with colleagues, and junior doctors may get a grudging day or so, usually without pay. This also applies for parental leave. It is hardly equitable.

\section{Parental rights}

There is no statutory or Whitley Council provision for parental leave in the UK, which is exceptional 
among developed countries. The measures suggested include the option of three months' leave per parent per child aged under 2 (Equal Opportunities Commission briefing, 22 May 1986). The arguments in favour of such provision that seem to me to have some force are the following: (a) It might be good for the children and would certainly be good for the fathers. (b) If it is true in developed countries elsewhere why should the UK be different? (c) It would increase employment opportunities. (d) If the leave is unpaid the costs of such leave (except to the person taking it) are minimal. (e) It makes it more likely that some of the burdens and opportunities associated with childrearing will be shared by fathers. $(f)$ If men doctors were known to be inclined to take time off for child care women doctors would be less likely to be regarded as problems and the opprobrium associated with the needs of women doctors during pregnancy would decrease. $(g$ ) Such a change in attitude would improve the career prospects and lifetime earnings of women doctors. Both are much lower for women doctors than can possibly be justified by any difference between the sexes in the average number of hours worked.

Some might argue that men doctors prefer to leave the rearing of their children to others but when given the opportunity to participate they seem to like it.

The well recognised maternal deprivation of mothers who are engrossed in careers pales into insignificance when compared with that of doctor fathers. A legal upper limit of, for example, 80 hours of work a week for doctors (compare lorry drivers) would also help. In the United States there has been a recent ruling that working over 80 hours a week is illegal. ${ }^{4}$

In 1986 the UK exercised its veto to prevent the introduction of a European Economic Community directive providing for parental leave. At this time there were 10 member states of the community and the other nine were in favour of the proposed directive. It is extraordinary that the full power of the veto was used against such a measure. Provision for parental leave already exists in Belgium, Denmark, France, Ireland, Italy, Luxembourg, Portugal, Spain, Sweden, and West Germany. In 1985 a House of Lords Select Committee pronounced in favour of such a measure. It is the subject of the Cohen Bill, which is to be reintroduced to the House of Commons in the next session of parliament. The introduction of parental leave has been strongly supported by the BMA and the Medical Women's Federation.

\section{Recommendations and conclusion}

(1) There is an urgent need to modify Whitley Council provisions to harmonise with the new statutory provisions.

(2) Inappropriate internal inconsistencies in Whitley Council provisions should be resolved.

(3) The whole system of maternity rights as applied to doctors needs to be examined and simplified.

Because the BMA represents the whole range of concerns of doctors, maternity rights, which affect women doctors only and are falsely regarded as doing so only in the short term, tend to escape attention. The Medical Women's Federation has paid close attention to the subject. I recommend ${ }^{4}$ that the BMA should set up a working party jointly with the federation, with strong representation from junior doctors and input from the Equal Opportunities Commission and the European Community. The working party should report within the year on desirable changes to the system and how they may be achieved. In a second stage paternity and parental rights should be considered.

In the 1990s the supply of young people, on which medical services in the UK have relied, will decrease. Managers, including doctor-managers, will have to consider how to retain and use to best advantage all categories of skilled staff. What has not been achieved in terms of maternity, paternity, and parental rights for doctors by other means may be helped along by demographic imperatives.

1 Beaumont B, Grüneberg A. The new consultant contract and women senior registrars. Br Med J 1979;i:359-60.

2 Gardin SK, Richwald GA. Pregnancy and employment leave: legal precedent and future policy. $\mathcal{F}$ Public Health Policy 1986;7:458-69.

Maternity Alliance. Maternity rights - the history. 59-61 Camden High Street, London NW1: Maternity Alliance, 1987.

4 Dyer C. American ruling on hours. Br Med f 1988:297:938-9.

\section{BOOKS RECEIVED}

\author{
Geriatrics \\ Interdisciplinary Topics in Gerontology. \\ Vol 24. "Regulation of Neuroendo- \\ crine Aging." Ed A V Everitt, J R \\ Walton. Series editor H P von Hahn. \\ (Pp 164; figs; f63.70.) Basel: Karger, \\ 1988. Distributed by John Wiley and \\ Sons. ISBN 3-8055-4770-6.

\section{Haematology} \\ Methods in Hematology. Vol 19. "Red \\ Cell Membranes." Ed S B Shohet, N \\ Mohandas. (Pp 344; figs; 149.50 .) \\ Mohandas. (Pp 344; figs; $\{49.50$.) \\ 1988. ISBN 0-443-08352-5.

\section{Histology} \\ Visual Histology. D T Moran, J C \\ Rowley III. (Pp 304; figs; £15.) Phil- \\ adelphia: Lea and Febiger, 1988 \\ ISBN 0-8121-1062-5. \\ History of medicine \\ Cambridge History of Medicine. "Pro- \\ fessional and Popular Medicine in \\ France, 1770-1830. The Social World \\ of Medical Practice." M Ramsey. \\ of Medical Practice." M Ramsey. \\ Series editors C Webster, \\ Rosenberg. (Pp 424; \{35.) Cambridge: \\ ISBN 0-521-30517-9.
}

Homoeopathy

Homeopathy: Medicine for the 2Ist Century. D Ullman. (Pp 300; $\$ 12.95$ paperback. California: North Atlantic Books, 1988. ISBN 1-55643-015-9.

\section{Immunology}

Principles of Immunology and Immunodiagnostics. R M Aloisi. (Pp 256; figs; $£ 15$ paperback.) Philadelphia: Lea and Febiger, 1988. ISBN 0-8121-1133-8.

Intensive care

Perspectives in Psychiatry. The Worcester Lectures. Ed P Hall, P D Stonier. (Pp 216; £21.50.) Chichester: Wiley, 1988. ISBN 0-471-91957-8.

Medical ethics

Ethics: the Heart of Health Care. D Seedhouse. (Pp 176; £8.85 paperback.) Chichester: Wiley, 1988. ISBN 0-471-91874-1.

\section{Nephrology}

Colour Aids Series. "Nephrology." J L Anderton, D Thomson. (Pp 111; colour plates; $\{5.95$ paperback.) Edinburgh: Churchill Livingstone, 1988. ISBN 0-443-03286-6.

Diagnosis and Management of Renal
Disease and Hypertension. A K Mandal, J C Jennette. (Pp 560; figs; $\{45$. Philadelphia: Lea and Febiger, 1988. ISBN 0-8121-1129-X.

New Clinical Applications: Nephrology. "Chronic Renal Failure." Volume and series editor G R D Catto. (Pp 176 figs; £35.) Dordrecht: Kluwer, 1988 ISBN 0-7462-0048-X.

New Clinical Applications: Nephrology. "Management of Renal Hyperten "Management of Renal Hypertension." G R D Catto. (Pp 240; figs £40.) Lancaster: MTP

Textbook of Renal Disease. Ed J A Whitworth, J R Lawrence. (Pp 420 figs; $£ 24.95$ paperback.) Melbourne: Churchill Livingstone, 1987. ISBN 0-443-02853-2.

Nuclear medicine

An Atlas of Clinical Nuclear Medicine. I Fogelman, M Maisey. (Pp 960; figs and colour plates; \&115.) London: Dunitz, 1988. ISBN 0-948269-34-0.

\section{Nursing}

An Introduction to the Social History of Nursing. R Dingwall, A M Rafferty, C Webster. (Pp 268; $£ 30$ hardback, £10.95 paperbark.) London: Routledge, 1988. ISBN hardback 0-415 ledge, 1988. ISBN hardback 0-4

\section{Nutrition}

World Review of Nutrition and Dietetics. Vol 57. "Aspects of Human Nut tion." Volume and series editor G H Bourne. (Pp 344; figs; £135.) Basel: Karger, 1988. Distributed by Joh Wiley and Sons. ISBN 3-8055-4810-9.

Obstetrics and gynaecology

Obstetrics and Gynaecology Revision MCQs, Case Histories and Picture Inlerpretation. D I M Farquharson. ( $\mathrm{Pp}$ 244; figs; £12.95 paperback.) Edinburgh: Churchill Livingstone, 1988. ISBN 0-443-03830-9.

\section{Occupational medicine}

Wiley Series on Studies in Occupationa Stress. "Causes, Coping and Consequences of Stress at Work." Ed C L Cooper, R Payne. Series editors C L Cooper, S V Kasl. (Pp 432; £29.95.) Chichester: Wiley, 1988. ISBN 0-47191879-2.

\section{Oncology}

Cancer Treatment and Research. "Endocrine Therapies in Breast and Prostate Cancer." Ed C K Osborne. Series editor W L McGuire. (Pp 176 figs; 37 95.) Boston: Kluwer, 1988 ISBN 0-89838-365-X
Pathology

Biopsy Pathology Series. "Biopsy Pathology and Cytology of the Cervix." D $\checkmark$ Coleman, D M D Evans. (Pp 416; figs; 448.50 .) London: Chapman and Hall. ISBN 0-412-25460-3.

Miscellaneous

The Alphabet and the Brain. The Lateralization of Writing. Ed D de Kerckhove, C J Lumsden. (Pp 472; figs; DM 168.) Berlin: Springer, 1988 ISBN 3-540-18122-9.

Avebury Series in Philosophy. "Ethics, Technology and Medicine" Ed D Brine, H Lesser. (Pp 160; Ed Aldershot: Avebury, 1988. ISBN $0-566-05249-0$

The Beat Fatigue Workbook. How to identify the causes and discover new vitality. L Chaitow. (Pp 192; £6.99 paperback.) Wellingborough: Thorsons, 1988. ISBN 0-7225-1550-2.

Behcet's Disease: a Contemporary Synopsis. Ed G R Plotkin, J J Calabro, J D O'Duffy. (Pp 320; figs; \$62.) New York: Futura, 1988. ISBN 0-87993 313-5.

A Family at Law. D Stewart, G Campbell. (Pp 256; figs; $£ 5.95$ paperback.) London: Fourmat, 1988. ISBN 1-85190-044-6. 